\title{
The future potential of Annona muricata L. extract and its bioactive compounds as radiation sensitizing agents: proposed mechanisms based on a systematic review
}

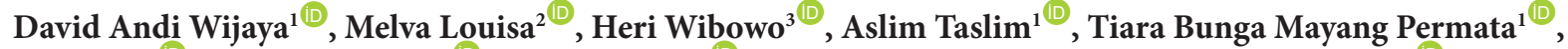

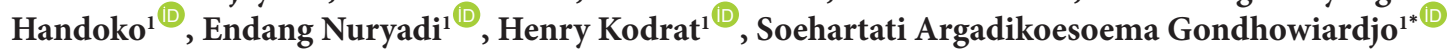 \\ ${ }^{1}$ Department of Radiation Oncology, Dr. Cipto Mangunkusumo National General Hospital - Faculty of Medicine, Universitas Indonesia, Jl. Salemba \\ Raya No. 6, Jakarta, Indonesia \\ 2Department of Pharmacology and Therapeutics, Faculty of Medicine, Universitas Indonesia, Jl. Salemba Raya No. 6, Jakarta, Indonesia \\ ${ }^{3}$ Laboratorium Terpadu, Faculty of Medicine, Universitas Indonesia, Jl. Salemba Raya No. 6, Jakarta, Indonesia
}

\section{A R T I C L E I N F O}

Article Type:

Review

\section{Article History:}

Received: 11 July 2020

Accepted: 29 September 2020

\section{Keywords:}

Annona muricata

Radiotherapy

Radio-sensitivity

Plant extract

Bioactive compounds

\begin{abstract}
A B S T RA C T
Despite technological advances in cancer treatment, especially in radiotherapy, many efforts are being made in improving cancer cell radio-sensitivity to increase therapeutic ratio and overcome cancer cell radio-resistance. In the present review, we evaluated the anticancer mechanism of Annona muricata L. (AM) leaves extract and its bioactive compounds such as annonaceous acetogenins, annomuricin, annonacin, or curcumin; and further correlated them with the potential of the mechanism to increase or to reduce cancer cells radiosensitivity based on literature investigation. We see that AM has a promising future potential as a radio-sensitizer agent.
\end{abstract}

Implication for health policy/practice/research/medical education:

This systematic review gathers evidence about the anticancer mechanism of Annona muricata while highlights related potential mechanisms of A. muricata as a radio-sensitizer, which can help enlightening the new radio-sensitizer drugs discovery.

Please cite this paper as: Wijaya DA, Louisa M, Wibowo H, Taslim A, Permata TB, Handoko, et al. The future potential of Annona muricata L. extract and its bioactive compounds as radiation sensitizing agents: proposed mechanisms based on a systematic review. J Herbmed Pharmacol. 2021;10(2):166-178. doi: 10.34172/jhp.2021.18.

\section{Introduction}

Notwithstanding technological advances in cancer treatment modalities, cancer is still a challenging disease for medical experts. According to GLOBOCAN 2018, more than 18 million new cases and 9.6 million mortalities were estimated in 2018. One among five men and one among six women are diagnosed with cancer throughout life. Moreover, one among eight men and one among eleven women die from cancer (1).

Many efforts have been made to increase the ratio between the probability of tumor control and the chance of normal tissue damage, known as a therapeutic ratio. Although radiotherapy technology is developing rapidly and has brought along new techniques able to increase therapeutic ratio, tumor radio-resistance is still a big challenge for oncologists.

Many studies have reported the anticancer effect of Annona muricata L. (AM) extract and its bioactive compounds either using in vitro or in vivo preclinical studies. However, so few studies observed the combination of radiation and AM in cancer cell lines that not enough evidence is available to conclude the role of AM in altering cell lines radio-sensitivity. Therefore, we separate our searching strategy. In this review, we collected the anticancer mechanisms of AM and then further correlated them to radio-sensitizing possibility.

\section{Methods}

Search strategy

We performed a search in PubMed, Cochrane, EBSCO, 
and Scopus database using keywords "(Annona muricata) AND ((molecular target) OR mechanism OR pathway) AND (cancer OR tumor OR neoplasm OR malignancy OR antiproliferative), which resulted 285 articles in PubMed, 1 article in Cochrane, 22 articles in EBSCO, and 58 articles in Scopus). After initial searching, the articles were filtered to exclude duplicated studies, conference abstracts, reviews/systematic reviews, letters/editorials, cases, and other irrelevant studies.

After that, we assessed the remaining articles to determine whether they met our inclusion criteria, using titles and abstracts. Our inclusion criteria were: (1) in vitro (cell lines) or in vivo (animal study) trials; (2) studies using AM extracts or its bioactive compounds; (3) studies analyzing/observing pathways or proteins occupied by AM to take effect. We chose to rule out articles which not discuss the working mechanism of AM specifically. We also did not include studies using molecular docking methods in order to observe the actual anticancer mechanisms of AM thoroughly.

We made a flow diagram in agreement with the Preferred Reporting Items for Systematic Reviews and Meta-Analyses (PRISMA) statement on systematic review reporting (see Figure 1) (2). Thenceforth, we did a full-text reading on 20 articles, and made a critical appraisal. Since there is no standard appraisal tool for in vitro studies, we used a reporting standard of Science in Risk Assessment and Policy (SciRAP) and Systematic Review Center for
Laboratory Animal Experimentation (SYRCLE). No article was ruled out in this critical appraisal and eventually we generated a summary. We then further analyzed and discussed the role of the pathways in enhancing cancer cell radio-sensitivity.

Cellular response to ionizing radiation: an overview Numerous cellular signaling pathways are induced after the cell was exposed to ionizing radiation, which will eventually generate responses like apoptosis, cellular senescence, and cell cycle checkpoint activation along with DNA repairing (3). Radiation, unfortunately, can also induce apoptosis-suppressing pathways like cell cycle arrest and DNA repair, which give the cell chance for rehabilitation $(4,5)$. They protect cancer cells from the killing effect of radiation, which significantly causes radio-resistance (6).

If DNA repair after a single-strand break (SSB) and double-strand break (DSB) fails, the intrinsic apoptotic pathway is activated (7). Longer and stronger activation of p53 has been correlated with higher chances of apoptosis rather than growth arrest (8). The intrinsic apoptotic pathway is regulated by the B-cell lymphoma (Bcl-2) proteins family, which consists of proapoptotic and antiapoptotic members (9).

Released Bcl-2 associated X protein (BAX) induces outer mitochondrial membrane permeabilization and consecutive cytochrome $\mathrm{c}$ discharge $(10,11)$. Accordingly,

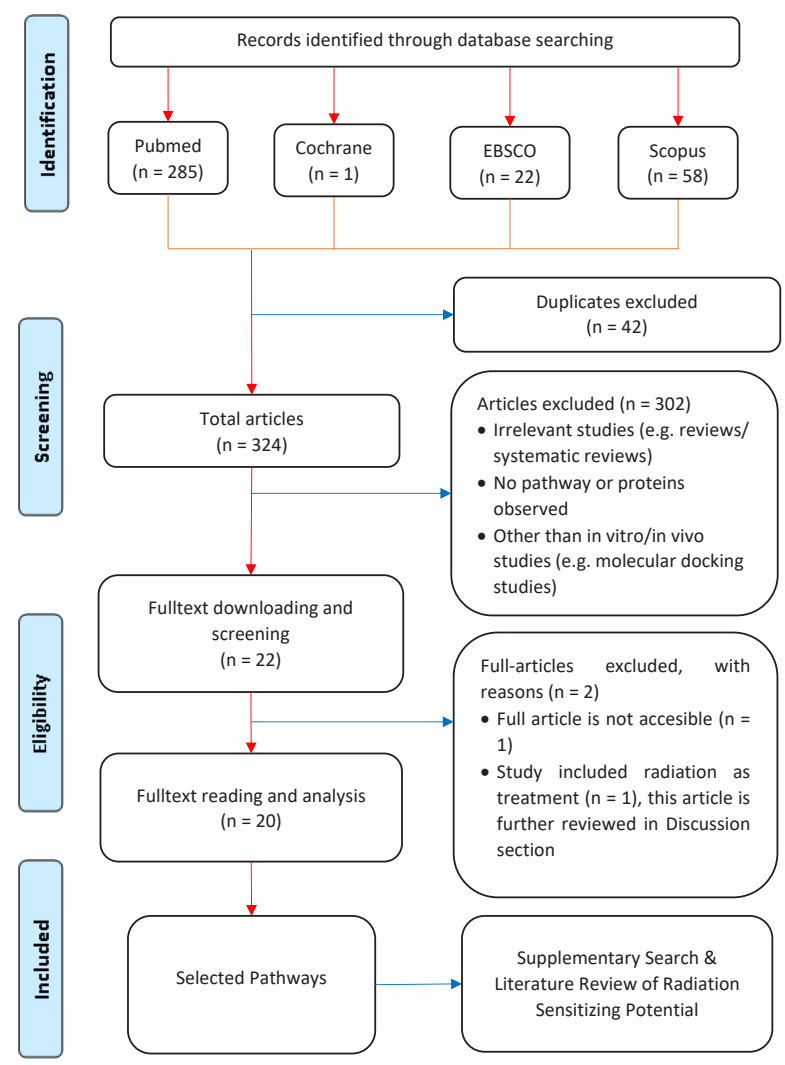

Figure 1. Flow diagram of the study. 
the release of cytochrome $\mathrm{c}$ into the cytosol will lead to the formation of cytochrome c/apoptotic protease activating factor 1 (APAF 1)/caspase-9 containing apoptosome complex (12). After that, caspases-3 and -7 as effector caspases will be activated, and will further lead to postmitochondrial-mediated caspase cascade (13).

The extrinsic apoptotic pathway, on the other hand, is regulated by the Fas-associated death domain (FADD) (14). CD 95 (well known as Fas) belongs to the tumor necrosis factor (TNF)-receptor superfamily. Its ligand CD95L (known as FasL or CD95L or CD178) is a transmembrane cytokine belonging to the TNF family (15). Radiation-induced p53 transactivates CD95, DR5, and the Fas ligand $(14,16)$.

FADD bridges Fas-receptor to procaspase-8, which interacts with the death effector domain of FADD, forming the death-inducing signaling complex, and ultimately activates procaspase- 3 and procaspase-7. Other downstream of CD95 could also activate caspases, which results in mitochondria-dependent mechanisms (17).

\section{Results}

Many published studies reported various pathways. We briefly summarised them in Table 1 according to the reporting author. We chose several main pathways, categorized them, and searched the radio-sensitivity evidence relating to the pathway and discussed them.

\section{Increased reactive oxygen species (ROS) formation}

Three studies have reported an increased ROS formation after AM administration (18-20). Among them, Moghadamtousi et al also explicitly reported that cytochrome $c$ was released from mitochondria upon apoptosis (20). As we know, radiation also induces apoptosis and cell damage via ROS formation. Any increased ROS, as opposed to decreased ROS formation in hypoxic cell conditions, will increase radiation efficacy (21).

\section{Inhibition at G2-M phase}

The cell cycle phase has been shown to determine the relative radio-sensitivity of cells. The cells will be the most radio-sensitive in the $\mathrm{G} 2-\mathrm{M}$ phase, less sensitive in the G1 phase, and the least sensitive at the late S phase (22). AM has shown an inhibiting effect on the cell cycle G2-M phase (23), although there are different reports by other authors (see Discussion section). This cell cycle inhibition effect could enhance the radio-sensitivity of the cancer cells.

\section{Regulation of Bcl-2 family proteins}

a. Upregulation of Bax and downregulation of $B c l-2$ proteins Being known as the death triangle, the Bcl-2 family consists of 3 types of members (24). Antiapoptotic and proapoptotic Bcl-2 homologs occupy two corners among them: $\mathrm{Bcl}-2, \mathrm{Bcl}-\mathrm{xL}$, and $\mathrm{Mcl}-1$ as antiapoptotic protein members; and Bax and Bak as proapoptotic protein members. The third corner is occupied by indirect/direct activator $\mathrm{BH}-3$ only-proteins (25).

The mitochondrial pathway of cell death is controlled by the Bcl-2 protein family. The family is subdivided into an antiapoptotic group consisting of Bcl-2 itself, $\mathrm{Bcl}-\mathrm{xL}$, and myeloid cell leukemia sequence 1 (Mcl-1); and a proapoptotic group comprising Bax, Bak, Bok, and several Bcl-2 homology-domain 3 (BH3)-only containing proteins (26).

$\mathrm{Bcl}-2$ has been associated with increased radioresistance (27-29), and inhibiting Bcl-2 proteins using different strategies has been proven to increase radiosensitivity (30). While there is no direct application of activating Bax protein to increase sensitivity to radiation, Bax's overexpression has been correlated to radiosensitivity in head and neck cancer (31).

\section{b. Downregulation of $\mathrm{Mcl}-1$ protein}

Different with Bcl-2 and Bcl-xL, Mcl-1 is a shortlived protein with a high turnover rate (32). When the translation of the protein was stopped, the Mcl-1 protein declined rapidly. Sequestration by $\mathrm{BH} 3$-only proteins and phosphorylation reportedly regulates Mcl-1 degradation (33-37). Phosphorylation at threonine 163 by extracellular regulated kinase 1 and 2 (ERK1/2) slows Mcl-1 protein turnover, while phosphorylation by glycogen synthase kinase-3 $\beta$ (GSK-3 $\beta$ ) targets Mcl-1 will lead to ubiquitylation and proteasomal degradation $(34,36)$. As Mcl-1 was reported as an antiapoptotic protein group, the downregulation of $\mathrm{Mcl}-1$ protein would increase radiation potential.

Loss of mitochondrial membrane potential (MMP)

Pieme et al (38), Moghadamtousi et al (20), and Kuete et al (39) reported respectively in HL-60, A549, and CCRF-CEM leukemia cells that AM leaves extract has an antiproliferative effect through a loss of MMP. MMP is provoked by an asymmetric distribution of protons and other ions on both sides of the inner mitochondrial membrane. Some authors have reported that some pathways induce radioresistance by increasing MMP or inhibiting its deterioration. MMP is regulated by growth differentiation factor-15 (GDF15), MEK/ERKsignaling pathway, and histone deacetylase inhibitor. Therefore, MMP is a potential target for radio-sensitivity improvement (40).

Li et al proved the involvement of GDF15, a transforming growth factor beta (TGF- $\beta$ superfamily), in head and neck cancer radio-resistance, by triggering MMP and inhibiting intracellular ROS production (41). The effect of MEK-ERK on MMP and the developed resistance has been successfully countered using MEK-specific inhibitor. 
Table 1. Anticancer effects of Annona muricata (AM) and its reported pathways of mechanism

\begin{tabular}{|c|c|c|c|c|}
\hline Author & $\begin{array}{l}\text { Annona muricata L. plant } \\
\text { component/bioactive } \\
\text { compound }\end{array}$ & $\begin{array}{l}\text { In vitro cell lines/in vivo } \\
\text { models }\end{array}$ & Reported pathway or molecular target and results & Conclusion \\
\hline \multirow[b]{2}{*}{$\begin{array}{l}\text { Najmuddin } \\
\text { et al (49) }\end{array}$} & \multirow[b]{2}{*}{ - Crude leaves extract } & $\begin{array}{ll}\text { - } & \text { MCF-7 } \\
\text { - } & \text { MDA-MB-231 } \\
\text { - } & 4 \mathrm{~T} 1\end{array}$ & 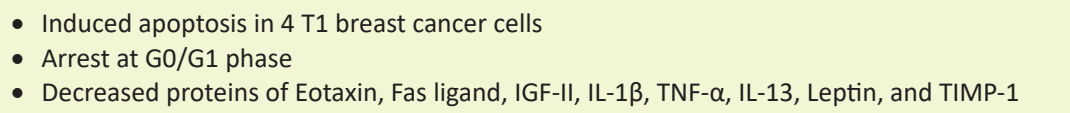 & \multirow[b]{2}{*}{$\begin{array}{l}\text { - Antiproliferative effect of AM crude extract on reported } \\
\text { cell lines and tumor-bearing mice }\end{array}$} \\
\hline & & $\begin{array}{l}\text { - T1-induced tumors } \\
\text { mice }\end{array}$ & $\begin{array}{l}\text { - Decreased proteins of Eotaxin, Fas ligand, IGF-IL, IL-1 } \beta \text {, TNF- } \alpha \text {, IL-13, Leptin, and TIMP-1 } \\
\text { - Decreased level of IGF-II } \\
\text { - Decreased level of inflammatory cytokines such as TNF- } \alpha \text { and IL-1ß } \\
\text { - Upregulated IFN- } \gamma \text { and Mig }\end{array}$ & \\
\hline $\begin{array}{l}\text { Pieme } \\
\text { et al (38) }\end{array}$ & $\begin{array}{l}\text { - Leaves, roots, and twig } \\
\text { extract }\end{array}$ & $\begin{array}{l}\text { - HL-60 cells (human } \\
\text { promyelocytic cells) }\end{array}$ & $\begin{array}{l}\text { - Apoptosis shown in treated cells, demonstrated cell shrinkage, chromatin condensation, } \\
\text { and fragmentation } \\
\text { - Mitochondrial membrane depolarisation } \\
\text { - Inhibited cell proliferation and arrested cells in the Go/G1 phase }\end{array}$ & $\begin{array}{l}\text { - Extracts from AM have strong antiproliferation potential } \\
\text { and can induce apoptosis through loss MMP and G0/G1 } \\
\text { phase cell arrest }\end{array}$ \\
\hline $\begin{array}{l}\text { Moghadamtousi } \\
\text { et al (20) }\end{array}$ & $\begin{array}{l}\text { - A. muricata L. leaves ethyl } \\
\text { acetate extract }\end{array}$ & $\begin{array}{l}\text { - A549 (human lung } \\
\text { cancer lines) }\end{array}$ & $\begin{array}{l}\text { - Induced G1 cell cycle arrest } \\
\text { - Increased generated ROS } \\
\text { - Induced caspase }-8,-9 \text {, and }-3 /-7 \text { activation } \\
\text { - Upregulation of BAX protein and downregulation of B-cell lymphoma Bcl-2 } \\
\text { - Suppressed NF-KB translocation } \\
\text { - Elevated translocation of cytochrome c from mitochondria to cytosol } \\
\text { - Attenuation of MMP }\end{array}$ & $\begin{array}{l}\text { - Annona muricata inhibited the proliferation of A549 } \\
\text { cells, leading to cell cycle arrest and programmed cell } \\
\text { death through activation of the mitochondrial-mediated } \\
\text { signaling pathway with the involvement of the NF-kB } \\
\text { signaling pathway }\end{array}$ \\
\hline $\begin{array}{l}\text { Chamcheu } \\
\text { et al (46) }\end{array}$ & $\begin{array}{l}\text { - Graviola leaf and stem } \\
\text { extract }\end{array}$ & $\begin{array}{l}\text { - UW-BCC1 } \\
\text { - A431 }\end{array}$ & $\begin{array}{l}\text { - Induce GO/G1 cell cycle arrest by downregulating cyclin/CDK factors and upregulating CDK } \\
\text { inhibitors } \\
\text { - Cleavage of caspases-3, }-8 \text { and poly (ADP-ribose) polymerase } \\
\text { - Suppression of activated hedgehog (Hh) pathway components Smo, Gli 1/2, and Shh while } \\
\text { inducing SuFu }\end{array}$ & $\begin{array}{l}\text { - Annona muricata leaf and stem extract dose-dependently } \\
\text { suppress UW-BCC1 and A431 cell growth, motility, wound } \\
\text { closure, and clonogenicity. }\end{array}$ \\
\hline $\begin{array}{l}\text { Moghadamtousi } \\
\text { et al (50) }\end{array}$ & - Annomuricin E & - HT-29 & $\begin{array}{l}\text { - Down-regulation of proliferating cell nuclear antigen and Bcl-2 proteins } \\
\text { - Upregulation of Bax protein } \\
\text { - The cytotoxic effect of annomuricin E was further substantiated by G1 cell cycle arrest and } \\
\text { early apoptosis induction. } \\
\text { - Leakage of cytochrome c from the mitochondria. } \\
\text { - Activation of caspase } 3 / 7 \text { and caspase } 9\end{array}$ & $\begin{array}{l}\text { - Annomuricin } E \text { as one of the contributing compounds in } \\
\text { the anticancer activity of AM leaves. }\end{array}$ \\
\hline $\begin{array}{l}\text { Yiallouris } \\
\text { et al (51) }\end{array}$ & $\begin{array}{l}\text { - Ethanol extract of Graviola } \\
\text { leaf }\end{array}$ & $\begin{array}{l}\text { - Hep2 } \\
\text { - Sum159 }\end{array}$ & $\begin{array}{l}\text { - Death of cancer cell lines partly mediated by induction of apoptotic pathway } \\
\text { - Graviola leaf extract inhibited sodium/potassium ATPase pump (NKA) activity and reduced } \\
\text { sarcoplasmic reticulum ATPase (SERCA) pump activity }\end{array}$ & $\begin{array}{l}\text { - AM leaf extract can promote selective cancer cell death } \\
\text { via inhibiting NKA and SERCA }\end{array}$ \\
\hline
\end{tabular}




\begin{tabular}{|c|c|c|c|c|}
\hline Author & $\begin{array}{l}\text { Annona muricata L. plant } \\
\text { component/bioactive } \\
\text { compound }\end{array}$ & $\begin{array}{l}\text { In vitro cell lines/in vivo } \\
\text { models }\end{array}$ & Reported pathway or molecular target and results & Conclusion \\
\hline $\begin{array}{l}\text { Kim } \\
\text { et al (18) }\end{array}$ & - Graviola leaf extract & - MDA-MB-231 & $\begin{array}{l}\text { - Triggered intrinsic apoptotic pathway through ROS formation in MDA-MB-231 TNBC } \\
\text { - ER-dependent apoptotic mechanism in MCF-7 cells }\end{array}$ & $\begin{array}{l}\text { - Induced mitochondrial apoptosis, suppressed cell } \\
\text { proliferation, and decreased cellular motility in MDA- } \\
\text { MB-231 }\end{array}$ \\
\hline $\begin{array}{l}\text { Abdullah } \\
\text { et al (45) }\end{array}$ & - A. muricata leaf extract & - COLO-205 & $\begin{array}{l}\text { - Higher value of caspase-3 activity than leucovorin and placebo in the COLO-205 colorectal } \\
\text { cancer cell line }\end{array}$ & $\begin{array}{l}\text { - Annona muricata leaf extract had anticancer properties } \\
\text { by enhancing caspase-3 activity, which is a proapoptotic } \\
\text { marker }\end{array}$ \\
\hline $\begin{array}{l}\text { Torres } \\
\text { et al (52) }\end{array}$ & $\begin{array}{l}\text { - Finely milled A. muricata } \\
\text { leaf/stem extract }\end{array}$ & $\begin{array}{l}\text { - } \mathrm{FG} / \mathrm{COLO357} \\
\text { - } \mathrm{CD} 18 / \mathrm{HPAF}\end{array}$ & $\begin{array}{l}\text { - Downregulation of molecules related to hypoxia and glycolysis in pancreatic cancer cells } \\
\text { (HIF-1 } \alpha \text {, NF-KB, GLUT1, GLUT4, HKII, and LDHA). }\end{array}$ & $\begin{array}{l}\text { - Inhibition of multiple signaling pathways that regulate } \\
\text { metabolism, cell cycle, survival, and metastatic properties } \\
\text { in pancreatic cancer cells }\end{array}$ \\
\hline $\begin{array}{l}\text { Md Roduan } \\
\text { et al (53) }\end{array}$ & $\begin{array}{l}\text { - Annonacin } \\
\text { - Curcumin }\end{array}$ & $\begin{array}{l}\text { - Two-stage mouse } \\
\text { skin tumorigenesis } \\
\text { with DMBA and TPA }\end{array}$ & - Better downregulation of AKT, ERK, mTOR, p38, and Src expression than curcumin. & $\begin{array}{l}\text { - Annonacin is a potential therapeutic compound targeting } \\
\text { tumor-promoting stage in skin tumorigenesis by } \\
\text { modulating multiple genes and protein in cancer signaling } \\
\text { pathways without apparent toxicity. }\end{array}$ \\
\hline $\begin{array}{l}\text { Kuete } \\
\text { et al (39) }\end{array}$ & - A. muricata leaf extract & - CCRF-CEM cells & - Induction of MMP-loss mediated apoptosis & $\begin{array}{l}\text { - AM is good cytotoxic plants that could be exploited } \\
\text { to fight mostly hematological cancers, including MDR } \\
\text { phenotypes. }\end{array}$ \\
\hline $\begin{array}{l}\text { Yap } \\
\text { et al (48) }\end{array}$ & - Annonacin (seeds) & $\begin{array}{l}\text { - EEC-1 } \\
\text { - EEC-1A } \\
\text { - EC6-ept } \\
\text { - EC14-ept }\end{array}$ & $\begin{array}{l}\text { - Apoptotic cell death was associated with an increase in caspase-3 cleavage and DNA } \\
\text { fragmentation }\end{array}$ & $\begin{array}{l}\text { - Cell apoptosis was accompanied by downregulation of } \\
\text { extracellular signal-regulated kinase survival protein } \\
\text { expression and induction of } \mathrm{G} 2 / \mathrm{M} \text { cell cycle arrest. }\end{array}$ \\
\hline $\begin{array}{l}\text { Magadi } \\
\text { et al (23) }\end{array}$ & $\begin{array}{l}\text { - Aqueous extract of Graviola } \\
\text { leaves }\end{array}$ & - SCC-25 & - Inhibition at G2M phase cell cycle & $\begin{array}{l}\text { - Graviola showed significant cytotoxic activity and } \\
\text { percentage of cell inhibition at G2M phase cell cycle } \\
\text { against SCC-25 cell lines }\end{array}$ \\
\hline Li et al (54) & - Annonaceous acetogenins & $\begin{array}{l}\text { Gastric cell lines: } \\
\text { - } \text { AGS } \\
\text { - } M K N-28 \\
\text { - MKN-45 } \\
\text { - SGC-7901 } \\
\text { - MGC-803 }\end{array}$ & $\begin{array}{l}\text { - Cell cycle arrest at G0/G1 phase } \\
\text { - Increased Notch2 expression }\end{array}$ & $\begin{array}{l}\text { - ACGs treatment in GC cells in vitro resulted in enhanced } \\
\text { cell proliferation inhibition, apoptosis, G0/G1 arrest, and } \\
\text { Notch2 expression. } \\
\text { - ACGs might inhibit proliferation and induce apoptosis } \\
\text { and G0/G1 arrest through directly or indirectly activating } \\
\text { Notch2. }\end{array}$ \\
\hline
\end{tabular}


Table 1. Continued

\begin{tabular}{|c|c|c|c|c|}
\hline Author & $\begin{array}{l}\text { Annona muricata L. plant } \\
\text { component/bioactive } \\
\text { compound }\end{array}$ & $\begin{array}{l}\text { In vitro cell lines/in vivo } \\
\text { models }\end{array}$ & Reported pathway or molecular target and results & Conclusion \\
\hline Han et al (55) & $\begin{array}{l}\text { - Annonaceous acetogenins } \\
\text { AA005 }\end{array}$ & $\begin{array}{l}\text { Human-colon- } \\
\text { carcinoma cell line } \\
\text { sW620 xenograft } \\
\text { nude mice }\end{array}$ & $\begin{array}{l}\text { - Increased nuclear translocation of AIF } \\
\text { - Downregulation of Mcl-1 through inhibition of transcription and translation } \\
\text { - Mcl-1 downregulation mediates in vivo antitumor effects of AA005 } \\
\text { - Mcl-1 downregulation induces RIP-1 activation }\end{array}$ & $\begin{array}{l}\text { - Anticancer effects of AA005 against human colon } \\
\text { cancer cell lines in vivo, which is mediated through the } \\
\text { downregulation of Mcl-1. }\end{array}$ \\
\hline Han et al (19) & $\begin{array}{l}\text { - Annonaceous acetogenins } \\
\text { AA005 }\end{array}$ & - sW620 & $\begin{array}{l}\text { - AA005 induces cell death through a caspase- } 3 \text { independent pathway } \\
\text { - ROS mediates AA005-induced cell death of SW620 cells } \\
\text { - RIP1 is required for AA005-induced cell death }\end{array}$ & $\begin{array}{l}\text { - AA005 may trigger the cell death via mediated by AIF } \\
\text { through caspase-3 independent pathway }\end{array}$ \\
\hline $\begin{array}{l}\text { Daddiouaissa } \\
\text { et al (56) }\end{array}$ & - IL-GFE & - MCF-7 & $\begin{array}{l}\text { - Growth inhibition of the cells by extracts was associated with cell cycle arrest at the G0/ } \\
\text { G1 phase, and phosphatidylserine externalization confirms the antiproliferation through } \\
\text { apoptosis. }\end{array}$ & $\begin{array}{l}\text { - IL-GFE affect the cytokinetics behavior of MCF-7 cells } \\
\text { by reducing cell viability, induce apoptosis and cell cycle } \\
\text { arrest at the GO/G1 phase }\end{array}$ \\
\hline Liu et al (57) & - Ethanol extract of AM & - HepG2 & $\begin{array}{l}\text { - Triggered cancer cell apoptosis through endoplasmic reticulum pathway: } \\
\text { - Upregulated phosphorylation of PERK and eukaryotic translation initiation factor-2 subunit } \\
\text { alpha } \\
\text { - Increase expression level of BIP and CHOP }\end{array}$ & $\begin{array}{l}\text { - Results indicate that the ethanol extract of leaves of AM } \\
\text { causes apoptosis of liver cancer cells through ER stress } \\
\text { pathway. }\end{array}$ \\
\hline Yang et al (58) & - Ethanol extract of AM & - HepG2 cells & $\begin{array}{l}\text { - Increased number of cells in the sub-G1 phase in a dose-dependent manner } \\
\text { - Apoptosis of the cancer cells. } \\
\text { - Produced ROS }\end{array}$ & $\begin{array}{l}\text { - Ethanol extract of AM leaves induces HepG2 cell } \\
\text { apoptosis through ROS pathway }\end{array}$ \\
\hline Ko et al (59) & - Annonacin & $\begin{array}{l}\text { - MCF-7 xenografts in } \\
\text { nude mice }\end{array}$ & $\begin{array}{l}\text { - Decreased cyclin D1 protein expression } \\
\text { - Increased apoptosis, while decreased Bcl-2 protein expression } \\
\text { - Decreased ER } \alpha \text { protein expression } \\
\text { - Decreased phosphorylation of ERK1/2, JNK and STAT3 }\end{array}$ & $\begin{array}{l}\text { - Annonacin induced growth arrest and apoptosis in ER } \alpha \text { - } \\
\text { related pathways in MCF-7 cells. }\end{array}$ \\
\hline
\end{tabular}

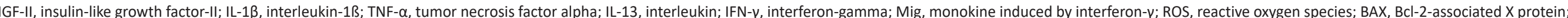

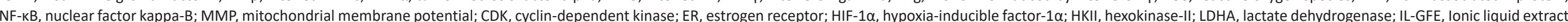
of Graviola fruit; AM, Annona muricata; mTOR, mammalian target of rapamycin; AIF, apoptosis-inducing factor; RIP-1, receptor interacting protein-1; MDR multidrug resistance. 
Suppressed nuclear factor kappa-B (NF- $\mathrm{B})$ translocation $N F-\kappa B$ was initially identified as a protein bound to a sequence in the immunoglobulin $\kappa$ light chain enhancer in $B$ cells. NF- $\kappa B$ can activate a significant number of genes involved in stress responses, inflammation, and programmed cell death (apoptosis). In mammals, the NF$\kappa \mathrm{B}$ family consists of five members of the Rel family: RelA (also called p65), RelB, c-Rel, p50/p105 (also called NF$\kappa B 1$ ), and p52/p100 (also called NF- $\kappa$ B2). The elevated basal NF- $\kappa \mathrm{B}$ activity in certain cancers has been linked with tumor resistance to chemotherapy and radiation (42). Therefore, as reported by several studies, suppression of NFkB will sensitize the radioresistant tumor cells (43).

Activation of caspase 3/7 and caspase 9

Caspase plays a vital role in apoptosis, with caspase- 8 activated via the extrinsic pathway and caspase-9 triggered by cytochrome $c$ release from mitochondria. Both intrinsic and extrinsic pathways will eventually progress through the executioner caspase- 3 and caspase- 7 (and also possibly caspase-6). Several reports have shown that caspase- 3 reconstitution in caspase- 3 deficiency cancer cells could significantly enhance radiation-induced apoptosis (44). By increasing caspase protein, especially caspase-3 $(19,20,45-48)$, it is expected that AM could sensitize cancer cells to radiation.

Downregulation of molecules related to hypoxia and glycolysis (HIF-1 a, GLUT1, GLUT4, HKII, LDHA) Hypoxia and glycolysis have been reported to be related to cancer cell radio-sensitivity. Many studies reported that hypoxia-inducible factor (HIF-1) regulates adaptive cellular responses to hypoxia. However, HIF-1 could also be activated and give rise to radio-resistance through cancer-specific genetic alterations and the disproportion of intermediate metabolites. HIF-1 has been reported recently to reduce cancer cell radio-sensitivity through glucose metabolism alteration and overproduction of antioxidants. In case that AM extract and its bioactive compounds could downregulate HIF-1 $\alpha$ expression, there is a prospect of reducing the cancer cell radio-resistance $(60,61)$.

GLUT expression was also reported in many studies to be correlated with radio-resistance (62-67), supposing that the AM can suppress the GLUT expression. This is a chance for radio-sensitizing the cancer cells. HexokinaseII (HK-II) was observed as a crucial glycolytic enzyme that initiates the first essential step of glucose metabolism. Zhong et al noted that HK-II could play a role in radioresistance of laryngeal carcinoma and remark the possibility of inhibiting the HK-II signaling pathway, which conceivably will enhance the radio-sensitivity (68).

Lactate dehydrogenase ( $\mathrm{LDH})$ plays a vital role in the tumor microenvironment as it converts pyruvate to lactate and vice versa (69). It is composed of two different subunits, encoded in humans by LDHA and LDHB genes
(70). Di et al reported that inhibiting this gene using siRNA mediated knockdown of LDHA will make cells more sensitive to radiation and chemotherapy in glioblastoma multiforme (GBM) (71). A similar finding has also been put forward in prostate cancer cells by Hao et al. When they used siRNA to inhibit the LDHA, the cells became more sensitive to radiotherapy (72). It is expected that AM could be a good radio-sensitizer by downregulating LDHA.

\section{Downregulation of Akt \& ERK}

The HER family of receptor tyrosine kinases (RTKs) consists of HER1, HER2, HER3, and HER4, which are located on the cell membrane (73). Phosphorylated tyrosines form docking sites for downstream adaptors and signal transducers, activating downstream signaling pathways including PI3K/Akt, Ras/Raf/MEK/ERK, phospholipase C-gamma/protein kinase C (PKC), and JAK/STAT pathway (74,75). Among those pathways, PI3K/Akt, and Ras/Raf/MEK/ERK cascades have been shown to play essential roles in cell survival after radiation (76).

Following radiation, ERK1/2 is activated through dual tyrosine and threonine phosphorylation by MEK $1 / 2$ and will further phosphorylate 160 substrates (77). The best characterized antiapoptotic transcription factors targeted by ERK1/2 signaling are the cyclic AMPresponsive element-binding protein $(\mathrm{CREB})$ and CAAT/ enhancer-binding protein $\beta(\mathrm{C} / \mathrm{EBP}-\beta)$. In response to radiation, ERK1/2 phosphorylates $\mathrm{p} 90^{\text {rsk }}$ kinase, which in turn activates CERB and C/EBP- $\beta$, thereby inducing the expression of a number of antiapoptotic proteins including Bcl-xL, Mcl-1, and c-FLIPs (77-80). Thus, by increasing the expression of antiapoptotic proteins and inhibiting the activity of proapoptotic proteins, the net effect of radiation-induced ERK1/2 signaling activation is the suppression of apoptosis in irradiated cells. Supposing that, by downregulating the ERK and Akt, AM may improve the radio-sensitivity.

Downregulation of cyclin D1, extracellular-signalregulated kinase-1/2 (ERK1/2), and signal transducer and activator of transcription-3 (STAT3)

Ko et al reported that AM could lower cyclin D1, ERK1/2, JNK, and STAT3 phosphorylation (59). Activation of STAT3 has been correlated with radio-resistance in triplenegative breast cancer (TNBC). When STAT3 is inhibited, TNBC sensitivity to radiation will be restored (81).

Janus kinase (JAK), especially JAK2 and signal transducer and activator of transcription, chiefly STAT3, was reported by Park et al to be activated in radioresistant CRC tissues, which grow persistently after delivered irradiation. It was also observed that cyclin D2 transcription, which is vital for maintaining intact cell cycle and proliferation despite DNA damage, is increased due to the direct binding of STAT3 to cyclin D2 (CCND2) 
promoter (82). Furthermore, Xie et al also reported that STAT3 and ERK1/2 dual blockage would resensitize GBM to radiotherapy (83).

Cyclin D1 is an important regulator, which is aided by cyclin-dependent kinase (CDK), controls the progression of the cell cycle at the G1/S transition $(84,85)$. Cyclin D1 has been reported in several studies to have a role in regulating radio-sensitivity and is an excellent target to increase cancer cell radio-sensitivity (84-88).

\section{Suppressed hedgehog signaling}

Chamcheu et al reported that AM extract could suppress the hedgehog signaling pathway (46). The hedgehog signaling pathway has been reported to be associated with radio-resistance in head and neck cancer, and also cervical cancer $(89,90)$. That opens an opportunity for AM to radiosensitize the cancer cells.

\section{Downregulation of mammalian target of rapamycin} (mTOR)

Integration between intracellular and extracellular signals is performed by mTOR. Moreover, mTOR also regulates cell metabolism, growth, proliferation, and survival. Many trials have concluded that the inhibition of mTOR could increase radio-sensitivity (91-93). Uniquely the opposite also applies: when the mTOR signal was enhanced, cancer became radio-resistant (94).

\section{Discussion}

There is a lack of trials that directly investigate the role of Annona muricata in combination with radiation. One of few works that we found is a publication from Mansour et al (95), which compared the effect of the addition of sole $\mathrm{AM}$, with radiation only, or in combination with $\mathrm{AM}$, and with placebo in Ehrlich ascites carcinoma bearing mice. They reported that a combination of AM and radiation reduced tumor volume more effectively, and the survival in the combination group was better than the irradiation alone group. Nevertheless, there is still controversy regarding the antioxidant role of AM, which was shown by significantly attenuated serum lipid profiles, decreased malondialdehyde and total nitrate/nitrite levels, DNA fragmentation, and significantly increased caspase- 3 and superoxide dismutase activity, glutathione content, and expression of glutathione peroxidase in the lung and kidney tissues compared with an irradiated group (95).

In the previous section, we discussed various pathways that could be effectively influenced (induced or inhibited) by AM extract or bioactive compounds, which in the end will increase cancer cell radio-sensitivity. We also found several pathways or proteins whose role has not been well studied, e.g., eotaxin, AIF, RIP-1. These pathways or proteins might be an exciting topic for further study.

Besides that, we also found distinct findings amongst different authors. Inhibition at the G2-M phase was reported by Magadi et al (23), while Moghadamtousi et al,
Syed Najmuddin et al, Pieme et al, Chamcheu et al, Li et al, and Yang et al reported a G0/G1 cell cycle arrest in their publications $(20,38,46,49,54,56,58)$. Neither of these two contrasting observations might be wrong, as they perform different observations in different cell lines. Several other findings are too general that we have some difficulties in finding the specific role of those findings. Among them are induced apoptosis, which was reported by Syed Najmuddin et al, Yiallouris et al, and Li et al $(49,51,54)$.

Nevertheless, we also found several pathways that could contrarily reduce radio-sensitivity. As we have discussed before, Fas-ligand plays an important role in the extrinsic apoptotic pathway (14-16). When Annona muricata reduces the Fas-ligand (49), in line with the study by Reap et al, it will reduce the radio-sensitivity of the cells (96). The way that AM upregulates PERK-eIF2 $\alpha$ (57) will also decrease the sensitivity of cells to radiation as PERK-eIF2 $\alpha$ signaling could give protection against ROS (97), and has been reported to correlate with radioresistance in oropharyngeal carcinoma (98). However, the role of PERK-eIF2 $\alpha$, including its downstream CCAAT/ enhancer-binding protein homologous protein (CHOP) and its initiator binding-immunoglobulin-protein (BIP) in potentiating radiation might not be studied clearly as this endoplasmic reticulum stress pathway may serve prosurvival or proapoptotic function depends on the severity of stress conditions (99).

Notch is a transmembrane protein (100) that regulates self-renewal and cell fate determination in normal stem cells (101). Annonaceous acetogenins from AM have been noted for showing an increased Notch expression in several cell lines (54). As Notch signaling pathway is correlated to cell radio-resistance by many authors, this will eventually result in reduced radio-sensitivity (100-105). Similarly, increasing TNF- $\alpha$ has been associated with the enhanced antitumor effect of radiotherapy. When AM decreased the TNF- $\alpha$ (49), radio-sensitivity will be lowered.

Another example is the downregulation of c-JUN $\mathrm{N}$-terminal kinase (JNK) by AM (59). Activation of the JNK is involved in damage response after ionizing radiation $(106,107)$. This pathway is initiated by mitogenactivated protein/extracellular signal-regulated kinase (MAP/ERK) (which is recognized as MEKK1) and requires MEKK4, JNK, and JUN to be consequently activated (108). This proapoptotic pathway of JNK could also be activated after membrane-derived signals, and subsequently releases ceramide $(106,108)$ and deathassociated protein 6 (DAXX), a CD95 binding protein (109). There is no direct study reporting the correlation of JNK and radio-resistance, but since JNK is proapoptotic, the downregulation of this protein might reduce the cancer cells killed by radiation.

\section{Conclusion}

Through our systematic review and further analysis of several main selected pathways, we revealed the future 
potential of $\mathrm{AM}$ as a promising radiation sensitizing agent. There are significant reported pathways or proteins that hypothetically could be used by either extract or bioactive compounds of AM in enhancing the radiosensitivity, compared to few pathways and mechanisms that conversely could reduce the radio-sensitivity. What we theoretically assume might be different in clinical applicability and reality. One of the challenges is, for example, the fundamental question of what effect this extract or bioactive compounds could induce to healthy cells surrounding the tumor. Hence, further in vitro or in vivo studies are needed to establish the evidence of this radio-sensitizing potential.

\section{Authors' contributions}

All of the authors participated in the planning of this study. DAW, ML, and AT were responsible for the critical appraisal process. HW, TBMP, H, EN, HK, SAG were responsible for the interpretation and discussion of the appraisal results. All of the authors read and agreed to the final manuscript for publication.

\section{Conflict of interests}

All authors declared no conflict of interest.

\section{Ethical considerations}

Ethical issues (including plagiarism, data fabrication, double publication etc) have been completely observed by the authors.

\section{Funding/Support}

This study was funded by International Publication Grant from the Universitas Indonesia (grant number NKB-2203/ UN2.RST/HKP.05.00/2020).

\section{References}

1. Bray F, Ferlay J, Soerjomataram I, Siegel RL, Torre LA, Jemal A. Global cancer statistics 2018: GLOBOCAN estimates of incidence and mortality worldwide for 36 cancers in 185 countries. CA Cancer J Clin. 2018;68(6):394-424. doi: 10.3322/caac.21492.

2. Moher D, Liberati A, Tetzlaff J, Altman DG. Preferred reporting items for systematic reviews and meta-analyses: the PRISMA statement. BMJ. 2009;339:b2535. doi: 10.1136/ bmj.b2535.

3. Gewirtz DA. Growth arrest and cell death in the breast tumor cell in response to ionizing radiation and chemotherapeutic agents which induce DNA damage. Breast Cancer Res Treat. 2000;62(3):223-35. doi: 10.1023/a:1006414422919.

4. Raleigh DR, Haas-Kogan DA. Molecular targets and mechanisms of radiosensitization using DNA damage response pathways. Future Oncol. 2013;9(2):219-33. doi: $10.2217 /$ fon. 12.185

5. Hawkins AJ, Golding SE, Khalil A, Valerie K. DNA doublestrand break - induced pro-survival signaling. Radiother Oncol.2011;101(1):13-7. doi: 10.1016/j.radonc.2011.05.074.

6. Hein AL, Ouellette MM, Yan Y. Radiation-induced signaling pathways that promote cancer cell survival (review). Int J Oncol. 2014;45(5):1813-9. doi: 10.3892/ijo.2014.2614.

7. Gudkov AV, Komarova EA. The role of p53 in determining sensitivity to radiotherapy. Nat Rev Cancer. 2003;3(2):11729. doi: $10.1038 /$ nrc992.

8. Vousden KH. p53. Cell. 2000;103(5):691-4. doi: 10.1016/ S0092-8674(00)00171-9

9. Cory S, Adams JM. The Bcl2 family: regulators of the cellular life-or-death switch. Nat Rev Cancer. 2002;2(9):647-56. doi: $10.1038 / \mathrm{nrc883}$.

10. Dejean LM, Martinez-Caballero S, Manon S, Kinnally KW. Regulation of the mitochondrial apoptosis-induced channel, MAC, by BCL-2 family proteins. Biochim Biophys Acta. 2006;1762(2):191-201. doi: 10.1016/j.bbadis.2005.07.002.

11. Dogu Y, Díaz J. Mathematical model of a network of interaction between $\mathrm{p} 53$ and Bcl-2 during genotoxicinduced apoptosis. Biophys Chem. 2009;143(1-2):44-54. doi: $\quad$ 10.1016/j.bpc.2009.03.012.

12. Cain K, Bratton SB, Langlais C, Walker G, Brown DG, Sun XM, et al. Apaf-1 oligomerizes into biologically active approximately $700-\mathrm{kDa}$ and inactive approximately 1.4-MDa apoptosome complexes. J Biol Chem. 2000;275(9):6067-70. doi: 10.1074/jbc.275.9.6067.

13. Cain K, Brown DG, Langlais C, Cohen GM. Caspase activation involves the formation of the aposome, a large (approximately $700 \mathrm{kDa}$ ) caspase-activating complex. J Biol Chem. 1999;274(32):22686-92. doi: 10.1074/ jbc.274.32.22686.

14. Scaffidi C, Fulda S, Srinivasan A, Friesen C, Li F, Tomaselli KJ, et al. Two CD95 (APO-1/Fas) signaling pathways. Embo j. 1998;17(6):1675-87. doi: 10.1093/emboj/17.6.1675.

15. Micheau O. TRAIL, Fas Ligand, TNF and TLR3 in Cancer. Cham: Springer International Publishing; 2017. (Resistance to Targeted Anti-Cancer Therapeutics; vol. 12). doi:10.1007/978-3-319-56805-8.

16. Sheard MA. Ionizing radiation as a response-enhancing agent for CD95-mediated apoptosis. Int J Cancer. 2001;96(4):213-20. doi: 10.1002/ijc.1020.

17. Chen YR, Wang X, Templeton D, Davis RJ, Tan TH. The role of c-Jun N-terminal kinase (JNK) in apoptosis induced by ultraviolet $\mathrm{C}$ and gamma radiation. Duration of JNK activation may determine cell death and proliferation. J Biol Chem. 1996;271(50):31929-36. doi: 10.1074/ jbc.271.50.31929.

18. Kim JY, Dao TTP, Song K, Park SB, Jang H, Park MK, et al. Annona muricata leaf extract triggered intrinsic apoptotic pathway to attenuate cancerous features of triple negative breast Cancer MDA-MB-231 cells. Evid Based Complement Alternat Med. 2018;2018:7972916. doi: 10.1155/2018/7972916.

19. Han B, Wang TD, Shen SM, Yu Y, Mao C, Yao ZJ, et al. Annonaceous acetogenin mimic AA005 induces cancer cell death via apoptosis inducing factor through a caspase-3independent mechanism. BMC Cancer. 2015;15:139. doi: 10.1186/s12885-015-1133-0.

20. Zorofchian Moghadamtousi S, Abdul Kadir H H, Paydar M, Rouhollahi E, Karimian H. Annona muricata leaves induced apoptosis in A549 cells through mitochondrialmediated pathway and involvement of NF- $\mathrm{kB}$. BMC Complement Altern Med. 2014;14:299. doi: 10.1186/1472- 
6882-14-299.

21. Wang H, Jiang H, Van De Gucht M, De Ridder M. Hypoxic radioresistance: can ROS be the key to overcome it? Cancers (Basel). 2019;11(1). doi: 10.3390/cancers11010112.

22. Pawlik TM, Keyomarsi K. Role of cell cycle in mediating sensitivity to radiotherapy. Int J Radiat Oncol Biol Phys. 2004;59(4):928-42. doi: 10.1016/j.ijrobp.2004.03.005.

23. Magadi VP, Ravi V, Arpitha A, Litha, Kumaraswamy $\mathrm{K}$, Manjunath K. Evaluation of cytotoxicity of aqueous extract of Graviola leaves on squamous cell carcinoma cell-25 cell lines by 3-(4,5-dimethylthiazol-2-Yl) -2,5-diphenyltetrazolium bromide assay and determination of percentage of cell inhibition at G2M phase of cell cycle by flow cytometry: an in vitro study. Contemp Clin Dent. 2015;6(4):529-33. doi: 10.4103/0976-237x.169863.

24. Gavathiotis E. BCL-2 Family Proteins. New York, NY: Springer New York; 2019 (Methods in Molecular Biology; vol. 1877). doi: 10.1007/978-1-4939-8861-7.

25. Lukas J, Lukas C, Bartek J. Mammalian cell cycle checkpoints: signalling pathways and their organization in space and time. DNA Repair (Amst). 2004;3(8-9):997-1007. doi: $10.1016 /$ j.dnarep.2004.03.006.

26. Youle RJ, Strasser A. The BCL-2 protein family: opposing activities that mediate cell death. Nat Rev Mol Cell Biol. 2008;9(1):47-59. doi: 10.1038/nrm2308.

27. Lee JU, Hosotani R, Wada M, Doi R, Kosiba T, Fujimoto K, et al. Role of Bcl-2 family proteins (Bax, Bcl-2 and Bcl-X) on cellular susceptibility to radiation in pancreatic cancer cells. Eur J Cancer. 1999;35(9):1374-80. doi: 10.1016/s09598049(99)00134-3.

28. Condon LT, Ashman JN, Ell SR, Stafford ND, Greenman J, Cawkwell L. Overexpression of Bcl-2 in squamous cell carcinoma of the larynx: a marker of radioresistance. Int J Cancer. 2002;100(4):472-5. doi: 10.1002/ijc.10503.

29. Nix P, Cawkwell L, Patmore H, Greenman J, Stafford N. Bcl-2 expression predicts radiotherapy failure in laryngeal cancer. Br J Cancer. 2005;92(12):2185-9. doi: 10.1038/ sj.bjc. 6602647.

30. Li JY, Li YY, Jin W, Yang Q, Shao ZM, Tian XS. ABT-737 reverses the acquired radioresistance of breast cancer cells by targeting Bcl-2 and Bcl-xL. J Exp Clin Cancer Res. 2012;31(1):102. doi: 10.1186/1756-9966-31-102.

31. Csuka O, Remenár E, Koronczay K, Doleschall Z, Németh G. Predictive value of $\mathrm{p} 53, \mathrm{Bcl} 2$ and bax in the radiotherapy of head and neck cancer. Pathol Oncol Res. 1997;3(3):20410. doi: 10.1007/bf02899922.

32. Huber $S$, Oelsner $M$, Decker $T$, zum Büschenfelde CM, Wagner M, Lutzny G, et al. Sorafenib induces cell death in chronic lymphocytic leukemia by translational downregulation of Mcl-1. Leukemia. 2011;25(5):838-47. doi: 10.1038/leu.2011.2.

33. Czabotar PE, Lee EF, van Delft MF, Day CL, Smith BJ, Huang DC, et al. Structural insights into the degradation of Mcl-1 induced by BH3 domains. Proc Natl Acad Sci U S A. 2007;104(15):6217-22. doi: 10.1073/pnas.0701297104.

34. Domina AM, Vrana JA, Gregory MA, Hann SR, Craig RW. MCL1 is phosphorylated in the PEST region and stabilized upon ERK activation in viable cells, and at additional sites with cytotoxic okadaic acid or taxol. Oncogene. 2004;23(31):5301-15. doi: 10.1038/sj.onc.1207692.
35. Gomez-Bougie P, Ménoret E, Juin P, Dousset C, PellatDeceunynck C, Amiot M. Noxa controls Mule-dependent Mcl-1 ubiquitination through the regulation of the Mcl1/USP9X interaction. Biochem Biophys Res Commun. 2011;413(3):460-4. doi: 10.1016/j.bbrc.2011.08.118.

36. Maurer U, Charvet C, Wagman AS, Dejardin E, Green DR. Glycogen synthase kinase- 3 regulates mitochondrial outer membrane permeabilization and apoptosis by destabilization of MCL-1. Mol Cell. 2006;21(6):749-60. doi: 10.1016/j.molcel.2006.02.009.

37. Warr MR, Acoca S, Liu Z, Germain M, Watson M, Blanchette $\mathrm{M}$, et al. BH3-ligand regulates access of MCL1 to its E3 ligase. FEBS Lett. 2005;579(25):5603-8. doi: 10.1016/j.febslet.2005.09.028.

38. Pieme CA, Kumar SG, Dongmo MS, Moukette BM, Boyoum FF, Ngogang JY, et al. Antiproliferative activity and induction of apoptosis by Annona muricata (Annonaceae) extract on human cancer cells. BMC Complement Altern Med. 2014;14:516. doi: 10.1186/1472-6882-14-516.

39. Kuete V, Dzotam JK, Voukeng IK, Fankam AG, Efferth T. Cytotoxicity of methanol extracts of Annona muricata, Passiflora edulis and nine other Cameroonian medicinal plants towards multi-factorial drug-resistant cancer cell lines. Springerplus. 2016;5(1):1666. doi: 10.1186/s40064016-3361-4.

40. Tang L, Wei F, Wu Y, He Y, Shi L, Xiong F, et al. Role of metabolism in cancer cell radioresistance and radiosensitization methods. J Exp Clin Cancer Res. 2018;37(1):87. doi: 10.1186/s13046-018-0758-7.

41. Li YL, Chang JT, Lee LY, Fan KH, Lu YC, Li YC, et al. GDF15 contributes to radioresistance and cancer stemness of head and neck cancer by regulating cellular reactive oxygen species via a SMAD-associated signaling pathway. Oncotarget. 2017;8(1):1508-28. doi: 10.18632/ oncotarget.13649.

42. Orlowski RZ, Baldwin AS Jr. NF-kappaB as a therapeutic target in cancer. Trends Mol Med. 2002;8(8):385-9. doi: 10.1016/s1471-4914(02)02375-4.

43. Ahmed KM, Li JJ. NF-kappa B-mediated adaptive resistance to ionizing radiation. Free Radic Biol Med. 2008;44(1):1-13. doi:10.1016/j.freeradbiomed.2007.09.022.

44. Yang XH, Edgerton S, Thor AD. Reconstitution of caspase-3 sensitizes MCF-7 breast cancer cells to radiation therapy. Int J Oncol. 2005;26(6):1675-80.

45. Abdullah M, Syam AF, Meilany S, Laksono B, Prabu OG, Bekti HS, et al. The value of caspase- 3 after the application of Annona muricata leaf extract in COLO205 colorectal cancer cell line. Gastroenterol Res Pract. 2017;2017:4357165. doi: 10.1155/2017/4357165.

46. Chamcheu JC, Rady I, Chamcheu RN, Siddique AB, Bloch MB, Banang Mbeumi S, et al. Graviola (Annona muricata) exerts anti-proliferative, anti-clonogenic and pro-apoptotic effects in human non-melanoma skin cancer UW-BCC1 and A431 cells in vitro: Involvement of hedgehog signaling. Int J Mol Sci. 2018;19(6). doi: 10.3390/ijms19061791.

47. Zorofchian Moghadamtousi S, Karimian H, Rouhollahi E, Paydar M, Fadaeinasab M, Abdul Kadir H. Annona muricata leaves induce $\mathrm{G}_{1}$ cell cycle arrest and apoptosis through mitochondria-mediated pathway in human HCT116 and HT-29 colon cancer cells. J Ethnopharmacol. 
2014;156:277-89. doi: 10.1016/j.jep.2014.08.011.

48. Yap CV, Subramaniam KS, Khor SW, Chung I. Annonacin exerts antitumor activity through induction of apoptosis and extracellular signal-regulated kinase inhibition. Pharmacognosy Res. 2017;9(4):378-83. doi: 10.4103/ pr.pr_19_17.

49. Syed Najmuddin SU, Romli MF, Hamid M, Alitheen NB, Nik Abd Rahman NM. Anti-cancer effect of Annona Muricata Linn Leaves Crude Extract (AMCE) on breast cancer cell line. BMC Complement Altern Med. 2016;16(1):311. doi: 10.1186/s12906-016-1290-y.

50. Zorofchian Moghadamtousi S, Rouhollahi E, Karimian H, Fadaeinasab M, Firoozinia M, Ameen Abdulla M, et al. The chemopotential effect of Annona muricata leaves against azoxymethane-induced colonic aberrant crypt foci in rats and the apoptotic effect of acetogenin annomuricin E in HT-29 cells: a bioassay-guided approach. PLoS One. 2015;10(4):e0122288. doi: 10.1371/journal.pone.0122288.

51. Yiallouris A, Patrikios I, Johnson EO, Sereti E, Dimas K, De Ford C, et al. Annonacin promotes selective cancer cell death via NKA-dependent and SERCA-dependent pathways. Cell Death Dis. 2018;9(7):764. doi: 10.1038/ s41419-018-0772-x.

52. Torres MP, Rachagani S, Purohit V, Pandey P, Joshi S, Moore $\mathrm{ED}$, et al. Graviola: a novel promising natural-derived drug that inhibits tumorigenicity and metastasis of pancreatic cancer cells in vitro and in vivo through altering cell metabolism. Cancer Lett. 2012;323(1):29-40. doi: 10.1016/j. canlet.2012.03.031.

53. Md Roduan MR, Abd Hamid R, Mohtarrudin N. Modulation of cancer signalling pathway(s) in two -stage mouse skin tumorigenesis by annonacin. BMC Complement Altern Med. 2019;19(1):238. doi: 10.1186/s12906-019-2650-1.

54. Li Y, Ye J, Chen Z, Wen J, Li F, Su P, et al. Annonaceous acetogenins mediated up-regulation of Notch2 exerts growth inhibition in human gastric cancer cells in vitro. Oncotarget. 2017;8(13):21140-52. doi: 10.18632/ oncotarget.15502.

55. Han B, Cao YX, Li ZM, Wu ZX, Mao YQ, Chen HL, et al. Annonaceous acetogenin mimic AA005 suppresses human colon cancer cell growth in vivo through downregulation of Mcl-1. Acta Pharmacol Sin. 2019;40(2):231-42. doi: 10.1038/s41401-018-0025-7.

56. Daddiouaissa D, Amid A, Kabbashi NA, Fuad FAA, Elnour AM, Epandy M. Antiproliferative activity of ionic liquid-graviola fruit extract against human breast cancer (MCF-7) cell lines using flow cytometry techniques. J Ethnopharmacol. 2019;236:466-73. doi: 10.1016/j. jep.2019.03.003.

57. Liu N, Yang HL, Wang P, Lu YC, Yang YJ, Wang L, et al. Functional proteomic analysis revels that the ethanol extract of Annona muricata L. induces liver cancer cell apoptosis through endoplasmic reticulum stress pathway. J Ethnopharmacol. 2016;189:210-7. doi: 10.1016/j. jep.2016.05.045.

58. Yang H, Liu N, Lee S. Ethanol extract of Annona muricata. $\mathrm{L}$ induces liver cancer cell apoptosis through ROS pathway. Biomed Pharmacol J. 2016;9(3):919-25. doi: 10.13005/ bpj/1030.

59. Ko YM, Wu TY, Wu YC, Chang FR, Guh JY, Chuang LY. Annonacin induces cell cycle-dependent growth arrest and apoptosis in estrogen receptor- $\alpha$-related pathways in MCF-7 cells. J Ethnopharmacol. 2011;137(3):1283-90. doi: 10.1016/j.jep.2011.07.056.

60. Huang R, Zhou P-K. HIF-1 signaling: A key orchestrator of cancer radioresistance. Radiat Med Prot. 2020;1(1):7-14. doi: 10.1016/j.radmp.2020.01.006.

61. Harada H. Hypoxia-inducible factor 1-mediated characteristic features of cancer cells for tumor radioresistance. J Radiat Res. 2016;57(Suppl 1):i99-i105. doi: $\quad$ 10.1093/jrr/rrw012.

62. Airley RE, Loncaster J, Raleigh JA, Harris AL, Davidson SE, Hunter RD, et al. GLUT-1 and CAIX as intrinsic markers of hypoxia in carcinoma of the cervix: relationship to pimonidazole binding. Int J Cancer. 2003;104(1):85-91. doi: 10.1002/ijc. 10904.

63. Yan SX, Luo XM, Zhou SH, Bao YY, Fan J, Lu ZJ, et al. Effect of antisense oligodeoxynucleotides glucose transporter-1 on enhancement of radiosensitivity of laryngeal carcinoma. Int J Med Sci. 2013;10(10):1375-86. doi: 10.7150/ijms.6855.

64. Shen LF, Zhao X, Zhou SH, Lu ZJ, Zhao K, Fan J, et al. In vivo evaluation of the effects of simultaneous inhibition of GLUT-1 and HIF-1 $\alpha$ by antisense oligodeoxynucleotides on the radiosensitivity of laryngeal carcinoma using micro 18F-FDG PET/CT. Oncotarget. 2017;8(21):34709-26. doi: 10.18632/oncotarget.16671.

65. Luo XM, Xu B, Zhou ML, Bao YY, Zhou SH, Fan J, et al. Co-inhibition of GLUT-1 expression and the PI3K/ Akt signaling pathway to enhance the radiosensitivity of laryngeal carcinoma xenografts in vivo. PLoS One. 2015;10(11):e0143306. doi: 10.1371/journal.pone.0143306.

66. Kunkel $M$, Moergel $M$, Stockinger $M$, Jeong JH, Fritz G, Lehr HA, et al. Overexpression of GLUT-1 is associated with resistance to radiotherapy and adverse prognosis in squamous cell carcinoma of the oral cavity. Oral Oncol. 2007;43(8):796-803. doi: 10.1016/j. oraloncology.2006.10.009.

67. Bao YY, Zhou SH, Lu ZJ, Fan J, Huang YP. Inhibiting GLUT-1 expression and PI3K/Akt signaling using apigenin improves the radiosensitivity of laryngeal carcinoma in vivo. Oncol Rep. 2015;34(4):1805-14. doi: 10.3892/or.2015.4158.

68. Zhong JT, Zhou SH. Warburg effect, hexokinase-II, and radioresistance of laryngeal carcinoma. Oncotarget. 2017;8(8):14133-46. doi: 10.18632/oncotarget.13044.

69. Valvona CJ, Fillmore HL, Nunn PB, Pilkington GJ. The regulation and function of lactate dehydrogenase a: therapeutic potential in brain tumor. Brain Pathol. 2016;26(1):3-17. doi: 10.1111/bpa.12299.

70. Markert CL, Shaklee JB, Whitt GS. Evolution of a gene. Multiple genes for LDH isozymes provide a model of the evolution of gene structure, function and regulation. Science. 1975;189(4197):102-14. doi: 10.1126/science.1138367.

71. Di H, Zhang X, Guo Y, Shi Y, Fang C, Yuan Y, et al. Silencing LDHA inhibits proliferation, induces apoptosis and increases chemosensitivity to temozolomide in glioma cells. Oncol Lett. 2018;15(4):5131-6. doi: 10.3892/ol.2018.7932.

72. Hao J, Graham P, Chang L, Ni J, Wasinger V, Beretov J, et al. Proteomic identification of the lactate dehydrogenase A in a radioresistant prostate cancer xenograft mouse model for improving radiotherapy. Oncotarget. 2016;7(45):74269-85. doi: 10.18632/oncotarget.12368.

73. Navolanic PM, Steelman LS, McCubrey JA. EGFR family 
signaling and its association with breast cancer development and resistance to chemotherapy (Review). Int J Oncol. 2003;22(2):237-52.

74. Arteaga CL, Engelman JA. ERBB receptors: from oncogene discovery to basic science to mechanism-based cancer therapeutics. Cancer Cell. 2014;25(3):282-303. doi: 10.1016/j.ccr.2014.02.025.

75. Rexer BN, Arteaga CL. Intrinsic and acquired resistance to HER2-targeted therapies in HER2 gene-amplified breast cancer: mechanisms and clinical implications. Crit Rev Oncog. 2012;17(1):1-16. doi: 10.1615/critrevoncog.v17. i1.20.

76. Valerie K, Yacoub A, Hagan MP, Curiel DT, Fisher PB, Grant S, et al. Radiation-induced cell signaling: inside-out and outside-in. Mol Cancer Ther. 2007;6(3):789-801. doi: 10.1158/1535-7163.mct-06-0596.

77. Munshi A, Ramesh R. Mitogen-activated protein kinases and their role in radiation response. Genes Cancer. 2013;4(9-10):401-8. doi: 10.1177/1947601913485414.

78. Boucher MJ, Morisset J, Vachon PH, Reed JC, Lainé J, Rivard $\mathrm{N}$. MEK/ERK signaling pathway regulates the expression of $\mathrm{Bcl}-2, \mathrm{Bcl}-\mathrm{X}(\mathrm{L})$, and Mcl-1 and promotes survival of human pancreatic cancer cells. J Cell Biochem. 2000;79(3):355-69.

79. Aoudjit F, Vuori K. Matrix attachment regulates Fasinduced apoptosis in endothelial cells: a role for c-flip and implications for anoikis. J Cell Biol. 2001;152(3):633-43. doi: $10.1083 /$ jcb.152.3.633.

80. Jost M, Huggett TM, Kari C, Boise LH, Rodeck U. Epidermal growth factor receptor-dependent control of keratinocyte survival and Bcl-xL expression through a MEK-dependent pathway. J Biol Chem. 2001;276(9):6320-6. doi: 10.1074/ jbc.M008210200.

81. Lu L, Dong J, Wang L, Xia Q, Zhang D, Kim H, et al. Activation of STAT3 and Bcl-2 and reduction of reactive oxygen species (ROS) promote radioresistance in breast cancer and overcome of radioresistance with niclosamide. Oncogene. 2018;37(39):5292-304. doi: 10.1038/s41388018-0340-y.

82. Park SY, Lee CJ, Choi JH, Kim JH, Kim JW, Kim JY, et al. The JAK2/STAT3/CCND2 Axis promotes colorectal Cancer stem cell persistence and radioresistance. J Exp Clin Cancer Res. 2019;38(1):399. doi: 10.1186/s13046-019-1405-7.

83. Xie B, Zhang L, Hu W, Fan M, Jiang N, Duan Y, et al. Dual blockage of STAT3 and ERK1/2 eliminates radioresistant GBM cells. Redox Biol. 2019;24:101189. doi: 10.1016/j. redox.2019.101189.

84. Sherr CJ, McCormick F. The RB and p53 pathways in cancer. Cancer Cell. 2002;2(2):103-12. doi: 10.1016/s15356108(02)00102-2.

85. Giacinti C, Giordano A. RB and cell cycle progression. Oncogene. 2006;25(38):5220-7. doi: 10.1038/ sj.onc. 1209615 .

86. Nurhidayat AA, Afiati A, Usman HA, Hernowo BS. Peranan cyclin D1 dan VEGF terhadap respons radioterapi pada karsinoma nasofaring tidak berdiferensiasi stadium lanjut. Jambi Med J. 2018;6(2):105-14. doi: 10.22437/jmj. v6i2.5949.

87. Shimura T. Targeting the AKT/cyclin D1 pathway to overcome intrinsic and acquired radioresistance of tumors for effective radiotherapy. Int J Radiat Biol. 2017;93(4):3815. doi: 10.1080/09553002.2016.1257832.
88. Peng G, Cao RB, Li YH, Zou ZW, Huang J, Ding Q. Alterations of cell cycle control proteins SHP-1/2, p16, CDK4 and cyclin D1 in radioresistant nasopharyngeal carcinoma cells. Mol Med Rep. 2014;10(4):1709-16. doi: 10.3892/mmr.2014.2463.

89. Gan GN, Eagles J, Keysar SB, Wang G, Glogowska MJ, Altunbas $\mathrm{C}$, et al. Hedgehog signaling drives radioresistance and stroma-driven tumor repopulation in head and neck squamous cancers. Cancer Res. 2014;74(23):7024-36. doi: 10.1158/0008-5472.can-14-1346.

90. Liu C, Wang R. The roles of hedgehog signaling pathway in radioresistance of cervical cancer. Dose Response. 2019;17(4):1559325819885293. doi: $10.1177 / 1559325819885293$.

91. Zhang D, Xiang J, Gu Y, Xu W, Xu H, Zu M, et al. Inhibition of mammalian target of rapamycin by rapamycin increases the radiosensitivity of esophageal carcinoma Eca109 cells. Oncol Lett. 2014;8(2):575-81. doi: 10.3892/ol.2014.2186.

92. Jaboin JJ, Shinohara ET, Moretti L, Yang ES, Kaminski $\mathrm{JM}, \mathrm{Lu} \mathrm{B}$. The role of mTOR inhibition in augmenting radiation induced autophagy. Technol Cancer Res Treat. 2007;6(5):443-7. doi: 10.1177/153303460700600510.

93. Dai ZJ, Gao J, Kang HF, Ma YG, Ma XB, Lu WF, et al. Targeted inhibition of mammalian target of rapamycin (mTOR) enhances radiosensitivity in pancreatic carcinoma cells. Drug Des Devel Ther. 2013;7:149-59. doi: 10.2147/ dddt.s42390.

94. Sato K, Azuma R, Imai T, Shimokawa T. Enhancement of mTOR signaling contributes to acquired X-ray and C-ion resistance in mouse squamous carcinoma cell line. Cancer Sci. 2017;108(10):2004-10. doi: 10.1111/cas.13323.

95. Mansour HH, Elkady AA, Elrefaei AH, Hafez HF. Radioprotective, antioxidant and antitumor efficacy of Annona muricata L. leaf extract. Indian J Biochem Biophys. 2018;55(3):205-14.

96. Reap EA, Roof K, Maynor K, Borrero M, Booker J, Cohen PL. Radiation and stress-induced apoptosis: a role for Fas/Fas ligand interactions. Proc Natl Acad Sci U S A. 1997;94(11):5750-5. doi: 10.1073/pnas.94.11.5750.

97. Rouschop KM, Dubois LJ, Keulers TG, van den Beucken $\mathrm{T}$, Lambin P, Bussink J, et al. PERK/eIF2a signaling protects therapy resistant hypoxic cells through induction of glutathione synthesis and protection against ROS. Proc Natl Acad Sci U S A. 2013;110(12):4622-7. doi: 10.1073/ pnas.1210633110.

98. Qiao Q, Sun C, Han C, Han N, Zhang M, Li G. Endoplasmic reticulum stress pathway PERK-eIF2 $\alpha$ confers radioresistance in oropharyngeal carcinoma by activating NF-kB. Cancer Sci. 2017;108(7):1421-31. doi: 10.1111/ cas. 13260 .

99. Rutkowski DT, Kaufman RJ. That which does not kill me makes me stronger: adapting to chronic ER stress. Trends Biochem Sci. 2007;32(10):469-76. doi: 10.1016/j. tibs.2007.09.003.

100. Chiba S. Notch signaling in stem cell systems. Stem Cells. 2006;24(11):2437-47. doi: 10.1634/stemcells.2005-0661.

101. Wu J, Bresnick EH. Bare rudiments of notch signaling: how receptor levels are regulated. Trends Biochem Sci. 2007;32(10):477-85. doi: 10.1016/j.tibs.2007.09.002.

102. Chang L, Graham P, Hao J, Ni J, Deng J, Bucci J, et al. Cancer stem cells and signaling pathways in radioresistance. 
Oncotarget. 2016;7(10):11002-17. doi: 10.18632/ oncotarget.6760.

103. Shen Y, Chen H, Zhang J, Chen Y, Wang M, Ma J, et al. Increased Notch signaling enhances radioresistance of malignant stromal cells induced by glioma stem/progenitor cells. PLoS One. 2015;10(11):e0142594. doi: 10.1371/ journal.pone.0142594.

104. Wang J, Wakeman TP, Lathia JD, Hjelmeland AB, Wang XF, White RR, et al. Notch promotes radioresistance of glioma stem cells. Stem Cells. 2010;28(1):17-28. doi: 10.1002/ stem.261.

105. Yahyanejad S, Theys J, Vooijs M. Targeting Notch to overcome radiation resistance. Oncotarget. 2016;7(7):761028. doi: 10.18632/oncotarget.6714.

106. Verheij M, Bose R, Lin XH, Yao B, Jarvis WD, Grant S, et al.
Requirement for ceramide-initiated SAPK/JNK signalling in stress-induced apoptosis. Nature. 1996;380(6569):75-9. doi: $10.1038 / 380075 \mathrm{a} 0$.

107. Verheij M, Ruiter GA, Zerp SF, van Blitterswijk WJ, Fuks Z, Haimovitz-Friedman A, et al. The role of the stress-activated protein kinase (SAPK/JNK) signaling pathway in radiationinduced apoptosis. Radiother Oncol. 1998;47(3):225-32. doi: 10.1016/s0167-8140(98)00007-3.

108. Westwick JK, Bielawska AE, Dbaibo G, Hannun YA, Brenner DA. Ceramide activates the stress-activated protein kinases. J Biol Chem. 1995;270(39):22689-92. doi: 10.1074/jbc.270.39.22689.

109. Frisch SM, Vuori K, Kelaita D, Sicks S. A role for Jun-Nterminal kinase in anoikis; suppression by bcl-2 and crmA. J Cell Biol. 1996;135(5):1377-82. doi: 10.1083/jcb.135.5.1377. 